himself satisfied with the results obiained at the Argentine Observatory; the photographs of the moon at full and in the last quarter he thinks may be favourably compared with any obtained elsewhere which he had seen. He refers to "the very beauti'ul picture of the moon" made with the 4-feet refector at Melbourne, which was also exhibited at Philadelpbia, ard adds, he is not sure, if he had seen this elegant ptotograph before placing his own on exhibition, he would have ventured to compete. Dr. Gould rrmalks that much of the credit of the stellir photographs is due to the pure air of Cordoba, which is incredibly transparent on the not very numerous occasions when the : ky is really clear. The impressions on glass exhibited were of six different clusters, the plate of the cluster X Carinæ containing two images each of 185 stars, and that of $\eta$ Argus cont 4 ining 180 , and many of the stars as faint as the niith magnitude. Measurable photographs of not less than eighty-tour celestial objects have been secur.d. of which rineteen are duuble stars and the remainder clusters. The planets Jupiter, Mars, and Saturn, have also been photographed "with sufficient distinctness 10 show clearly the details of light and colour on the surfaces of the two former, and the existence of the ring in the latter," but the images have not been sufficiently sharp to allow of successful photographic enlargement.

VARIAPLE STARs,-Herr Palisa in Ast. Nach., No 2,174 , mentions his having remarked a new variable star, the position of which for $1877^{\circ} \mathrm{o}$ is in R.A. $16 \mathrm{~h} .4 \mathrm{~m} .35 \mathrm{~s}$, N.P D. $109^{\circ} 48^{\prime} 9$. It does not occur on Chacornac's chart No. 49 ; it was Iom. on May 26, 1876, and on Iuly $3 \mathrm{I}$ and August 3 of last year, whereas on May 17 , 1877 , no trace of it was percepible. The period is there fore no doubt con?paratively short.

The star L. $36606=$ B.A.C. 664 I appears to vary from $6.5 \mathrm{~m}$. to $9 \mathrm{~m}$. On October 17,1852 , Argelander estimated it of the former magnitude, Lalande and Piazzi call it an eighth, while about midsummer, 1851, it was little, if anything, over the ninth magnitude.

L. $262 \mathrm{II}$ is probably variable from $6 \mathrm{~m}$. to $8 \mathrm{~m}$., and L. 27307 from $7 \mathrm{~m}$. to $\mathrm{gm}$, and it is not unlikely that further observations will place $\dot{b}^{2}$ Geminorum on the list of variables; it has been rated at a filth magnitude and as low as $8 \frac{1}{2}$.

The Minor Planet Eva.--A planet of the eleventh magnitude, observed by Herr Palisa at Pola on December 29, is inentioned in the Bulletin International of J anuary 3, as possibly No. 180, but according to a communication from Herr Knorre, of Berlin, as probably identical with No. 164, detected by M. Paul Henry at Paris on July I2, 1876 , which received the name Eva. The observations of 1876 extended over an interval of little more than a fortnight, and the elements which have been calculated by Mr. Winslow Upton and M. Bossert are therefore liable to uncertainty, but if we adopt Mr. Upton's orbit and compute for the time of the Pola observation, the place is found to be about a degree only from that observed, and it is therefore probable that No. 180 has yet to be discovered.

\section{THOMAS VERNON WOLLASTON}

$T H E$ very limited band of scientific English entomologists has just suffered a great loss by the sudden drath, on the $4^{\text {th }}$ instant, at his residence, r, Barnepark Terrace, Teignmouth, of Thomas Vernon Wollaston-a name dear to science, and of which he well upheld the reputation. Accurate, elaborate, and precise ad punctum, and naturally of a minutely critical habit, he nevertheless persistently acted upon a broad conception of the science to which he was devoted; and taking advantage of the periodical banishments to a warmer climate imposed upon him in early manhood by pulmonary weakness, set himself the task of thoroughly investigating the coleopterous fauna of the Madeiras, Salvages, and Cape de Verdes, and finally of St. Helena. His philosophical deductions from the vast mais of well sifted evidence obtained (chiefi, by his own bodily toil, though he was always in a more or less debilitated state of health) referrin $\&$ to these isolated groups, may be summed up as corroboraing the former existence of that submerged Atlantis whereon geologists differ. From the exhaustive care with which his material was obtained, it seems highly unlikely that his premises were insufficient; and bis discussion of the subject so far resembles Mr. Darwin's method that it supplies the objections likely to be raised, and itself practically exhausts criticism by minuteness of observation.

To students of British entomology, Mr. Wollaston is best known by his rarly papers in the Znoloyist and stainton's Entomologists' Annual and Weekly Intelligencer, and by his revision of Atomaria in Trans. Ent. soc. 1877 His first scientific contribution was in the Zooloyist, vol. i. (1843, on Coleoptera at Launceston, when a student at Jrsus College, Cambridge (where, with the late J. F. Dawson and Hamlet Clark, he imbihed from Dr. Babington a taste for natural scienc $\rightarrow$ ), and his last, a piper in the Annals and Magazine of Natural History, on a wervil destructive to the banana in Marteira, was received from him by the writer almost simultaneously with the news of his death. He published many descriptive and analytical papers, almost exclusivels on Coleobtera, in the above-named publications, the Fouruai of Entomologv and the Entomologists' Montily Magazine; but his magnum opus is the well-known "Insecta Maderensia," published in 1854 , the results of his sojourns in Madeira, to which he first went in $184 \%$. This, from its amcunt of novelty and classical treatrnent, at once established his reputation.

His collection, increased by another visit in 1855 . having been purchased by the trustees of the British Museum, he prepared a more complete account, which was published as a museum "Catalogue" in 1857. Subsequent visits in 1858 and 1859 resulted in a description of the coleopterous fauna of the Canaries, also published as a museum "Catalogue" in 1864 . The acquisition of fresh material compelled him in the next year to wite his "Coleoptera Atlantidum," an arduous critical work of nearly 700 pages, followed in 1867 by the "Coleoptera Hesperidum," a valuable descriptive account of the species of the Cape Verde Archipelago, visited in I866. His last contribution to geographical entomology, "Coleopıera Sanctæ-Helenæ," I877, contains a multiplicity of unexpected developments (especially after the supposed exhaustion of the productions of the island in Mr. Melliss's work), and shows that St. Helena is the home of a special family, Cossonida, to which Mr. Wollaston had always devoted at:ention, having himself described no less than 255 new species in it, as against 67 described by all other naturalists, living or dead.

Of his other works, it may suffice to mention one on the "Variation of Species," published in 1856 , and another, "Testacea Atlantica," that will, alas, be posthumous (though complete), being a descriptive account of the land-shells of his favourite hunting-ground.

The amount of work in these publications and in others not referred to, is astonishing, especially to those who know the extreme precision (both in manipulation and writing) and the weak physical condition of the author. Mr. Wollaston became a Fellow of the Linnean Society in 1847 , and was also a Fellow of the Cambridge Philosophical Society, but, beyond his university degree, sought no other honorary distinction. He was, we believe, in his fifty-seventh year at the time of his death. E. C. R.

\section{NOTES}

We may remind our readers that on this day, a century ago, one of the great reformers of science-perhaps the most celebrated naturalist of all tịmes-Linné, breathed his list. Hiș 